\title{
ISSUE OF GRANT PROPERTY WITHDRAWAL IN ARTICLE 712 OF SHARIA ECONOMIC LAW COMPILATION AND ARTICLE 212 OF ISLAMIC LAW COMPILATION
}

\author{
Junaidi $^{1}$, Mila Surahmi ${ }^{2}$
}

\begin{abstract}
Grant is a unilateral agreement by a grantor that is carried out by the grantor to the grantee who gives goods free of charge to the grantee. This grant is carried out between the grantor and the grantee is still alive and well. In practice, there were many cases where grants were revoked or withdrawn by the grantor for certain reasons. Therefore, this study was conducted to determine the law of withdrawal of grants by the grantors. The research method used is juridical normative and the approach method used in the research is the library research approach. In Article 712 of the Sharia Economic Law Compilation explains that the grant property can be withdrawn by the grant if the grantee approves, whereas, in Article 212 Islamic Law Compilation, the grant cannot be withdrawn under any circumstances, except for a grant related to his child. issue of the difference between the withdrawal of grant property found in the Sharia Economic Law Compilation, if the grantee agrees and voluntarily returns the grant property that has been received and in the Islamic Law Compilation, the grant property can be withdrawn, namely a parent's grant to his child, this is because the grant property can be counted as inheritance as stipulated in Article 211 of Islamic Law Compilation. These two compilation laws are used and applied in the Religious Courts to resolve disputes for Muslim parties.
\end{abstract} Keywords: Grant Withdrawal, Grantee, Islamic Law Compilation, Sharia
Economics Law Compilation.

\section{The Introduction}

A grant, if it is seen as having similarities with gifts and alms, lies the difference in the intention and purpose of giving, are: a grant is the gift of an object free of charge without expecting a reward when it is still alive; a gift is a gift made to honor and glorify someone for an achievement he has achieved; and almsgiving is a gift made to someone who needs it (Idris Ramulyo, 2004 :116).

The main meaning of grant, in addition to the element of sincerity and willingness of a person in giving something to others is about the right of benefits and property rights. In Islamic law, a grant is a transfer of benefits and property rights from one person's wealth to another (Abdul Djamali, 2002: 180).

The application of the Sharia economy in Indonesia has given birth to its law, namely theSharia Economic Law Compilation. Sharia Economic Law Compilation was enacted in the settlement of disputes in the Religious Court with the issuance of Supreme Court Regulation No. 2 of 2008.

The Sharia Economic Law Compilation is a collection of economic law from various sources of Islamic law (Fiqh) that are aligned with the development of law and modern business practices, in its preparation it

${ }^{1}$ Universitas Sjakhyakirti Palembang, Email: junaidievy@yahoo.com

${ }^{2}$ Universitas Sjakhyakirti Palembang, Email: milamimi@unisti.ac.id 
adopts the systematics of the Civil Code. The Sharia Economic Law Compilation consists of 790 Articles, which are divided into 4 (four) books, namely Book I on legal subjects and amwal (property), Book II on contracts, Book III on zakat, and grants and Book IV on Sharia accounting. The grants specifically are regulated in Article 668 to Article 727. The provisions of the grant in it regulate the pillars, conditions, withdrawal of the grant, the limit of property granted, and grants to people who are seriously ill. Explanation in the Sharia Economic Law Compilation, grants can be made by (PPHIMM, $2009: 215)$ :

1. Exemption of debt from a person who has a debt against the person in debt provided that the person in debt does not refuse the debt relief;

2. A grant is given by someone by giving his property to another person while the property is a gift that he has not received, provided that the last recipient of the grant has received the gift.

Islamic Law Compilation was enacted based on Presidential Instruction No. 1 of 1991, June 19, 1991, and Decree of the Minister of Religion Number 154 of 1991, July 22, 1991. Arrangements on grants are regulated in Article 5, all of which are regulated in Chapter IV of Book II on Inheritance in Article 210 to Article 214 (Abdul Manan \& M. Fauzan, 2001 : 381).

Islamic Law Compilation and Sharia Economic Law Compilation is applied within the Religious Court, to obtain legal unity in examining and deciding matters for judges. These two compilations are to resolve disputes between Muslim parties in seeking justice.

The problem with grants that often occurs is the withdrawal of the grant property. Article 212 of Islamic Law Compilation states that grants cannot be withdrawn, except for grants from parents to their children.Regarding this, in the Islamic Law Compilation that can be considered as inheritance as Article 211 states that grants from parents to children can be counted as an inheritance. This is what makes it the reason for the withdrawal of the grant property given by parents to their children.

The Shariah Economic Law Compilation set out in Article 712 which states that the Grantor may withdraw his grant property after the submission is made, provided the recipient agrees. This means that the grant can be withdrawn if it has first obtained approval from the grantee, that the grantee voluntarily returns the grant property that has been given to him.

From these provisions, a grant is in principle non-refundable and the difference between the provisions of the withdrawal of grant property between the Shariah Economic Law Compilation and the Islamic Law Compilation on the condition that a grant can be withdrawn is a grant between parents and children arranged in the Islamic Law Compilation and grant can be withdrawn when the grantee voluntarily agrees to it as arranged in the Shariah Economic Law Compilation.

\section{Research methods}

The research method used is juridical normative which is the main plan in the development of science. The research approach is a system or way of conducting research (SuharsiniArikunto, $2002: 23$ ). The approach method used in the research is the library research approach, which is legal research conducted using library materials or secondary data consisting of primary 
legal materials, secondary legal materials, and tertiary legal materials (Soerjono Soekanto \& Sri Mamudji, $1995: 39$ ).

\section{Discussion and Results}

\section{Grants Withdrawal in Article 712 Sharia Economic Law Compilation}

The cancellation or withdrawal of the grantproperty has been regulated in Article 708 of the Sharia Economic Law Compilation which states that the grant is canceled if it occurs due to coercion and this is clarified in Article 712 of the Sharia Economic Laws Compilation which states that:

The grantor can withdraw the grantproperty after the delivery is carried out, provided the grantee agrees.

If the grantor withdraws the property of the gift without the consent of the grantee or a court decision, this is not permitted, because it is considered that the gifter has taken someone else's property if the item is damaged or lost while in his control, he must replace it these losses (KHES:173).

According to the Supreme Court Regulation No.2 of 2008 concerning the Sharia Economic Laws Compilation, it clearly states that grants have been given to parents, or their children, or brothers or sisters, or siblings' children, or aunt's uncle, after the transaction has occurred, it cannot be withdrawn unless the grant recipient agrees, this is regulated in Article 713 Sharia Economic LawCompilation. A grant that has been handed over cannot be withdrawn, because this grant has been implemented. However, it does not rule out that the property of the grant can be withdrawn, as according to Article 712 of the Sharia Economic LawsCompilation, the grantor can withdraw the property given after the delivery provided that the grantee agrees, this explains that the grantproperty can be withdrawn if obtained approval from the grantee, both from parents and relatives.

In Article 720 of the Sharia Economic Law Compilation states that:

If the wahib withdraws the mauhublah that has been submitted without the consent of the mauhublah or the decision of the Court, then the wahib is designated as a usurper of other people's goods, and if the goods are damaged or lost while under his control, then he must compensate.

The purpose of this article is that a grant can be withdrawn if a decision has been made by the court, even though the grantee does not give permission to withdraw the grant. it can be concluded that the grant can be withdrawn, with the following conditions:

1. Obtaining permission to withdraw a grant from the grantee or a court decision;

2. Grants from parents to biological children;

3. The grant given exceeds $1 / 3$ of the property;

\section{Withdrawal of Grants in Article 212 Islamic Law Compilation}

According to Article 212 Islamic Laws Compilation, it states that a grant cannot be withdrawn, except for a gift from the parent to the child. Cancellation or withdrawal of a grant is an act that is prohibited, even though the gift occurs between 2 (two) siblings or husband and wife. A grant 
that can be withdrawn is a grant from a parent to a child (Azni, 2015:106107). Grants given by parents to children can be withdrawn because it can be counted as part of the inheritance. Grants in civil law are prepaid (voorschot) as part of the inheritance for the heirs (Rusydi, 2016).

Withdrawal of grants from parents to their children is allowed because of the great service parents provide to their children. Parents who have gone to great lengths to raise, nurture and educate them to maturity, so that human withdrawal can be justified as a form of appreciation and respect for them (Abdurrahman, 2018).

The Islamic Law Compilation allows the gift of $1 / 3$ of the property he owns, while the gift from parents to children can be considered as inheritance, this is as stipulated in Article 211 Islamic Law Compilation. According to Muhammad IbnHasan, that someone who gives away all his property is a fool and is incapable of acting in law. Therefore, what it does becomes null and void because it does not fulfill the requirements to implement the grant (Abdul Manan, 2008: 138).

Based on the description above, it can be concluded that in principle, a grant cannot be canceled or withdrawn. If it given exceeds $1 / 3$ of his property, it can be canceled, because it does not meet the requirements for giving the grant, as regulated in Article 210 of the Islamic Law Compilation which states:

(1) A person who has been at least 21 years of age with good sense without coercion can grant up to $1 / 3$ of his property to another person or institution in front of two witnesses for a possession;

(2) The property given must be the right of the grantor.

\section{The Law of Withdrawing Property Grants in Fiqh}

The grant agreement is invalid unless a handover has been made. This resulted in 2 (two) phases from the permanence side of the grant, namely the phase before being handed over and phase after the handover occurs. The phase before being handed over, currently, the nature of grants is not permanent. The majority of scholars argue with the hadith of Umm Kulthumbint Abu Salamahradhiyallahuanhuma, which states that:

"When RasûlullâhSallallahu 'alaihiwasallam married Umm SalamahRadhiyallahuanhuma, He said to her, "Really I have given Najasyi a gift in the form of clothes and several bottles of misk and I am sure Najasyi has died and my gift will be returned to me. When it is returned to me it will be yours. "Umm KultsumRadhiyallahuanhuma said, "And it happened as RasûlullâhShallallahu 'alaihiwasallam said and returned the gift to Him, then He gave each wife a bottle of misk oil and gave the remaining oil and clothing to Umm Salamah". HR. Ahmad and IbnHibban, but this hadith is considered weak by Shaykh al-Albani in al-Irwa', no. 1620].

A grant is a tabarru (non-profit) contract. If the grant is valid without a handover, of course, the one who is given the grant has the right to demand that the grantor give the gift to him so that it becomes a dhaman (compensation) contract, this is inappropriate. Also, the withdrawal of the grant before the handover occurs shows that the grantor is not happy with 
the gift. If forced to surrender, it is the same as issuing property without pleasure. This goes against the very nature of the grant.

The phase after the handover occurs. Grants in this situation are permanent and binding so they cannot be withdrawn, as RasûlullâhShallallahu 'alaihiwasallam says in his words: "The person who withdraws his gift is like a dog who licks back his vomit” [HR. Al-Bukhâri].

Also the words of Rasûlullâh Shallallahu 'alaihiwasallam: "It is not permissible for a person who gives a gift or gift and then he withdraws the gift unless it is given by the parents to his child". [Narrated by Ahmad, Ibn Hibban, and Abu Dawud. This hadith is considered authentic by Shaykh alAlbanirahimahullah in Shahîh al-Jami, no. 2775].

Thus, it is clear that after handover, the grant becomes the property that is given and it is prohibited to withdraw.

\section{Conclusion}

In principle, the Sharia Economic Law Compilation and Islamic Law Compilation do not allow withdrawal of the grant property that have been given. When viewed from the time of the grant contract as in Islamic Fiqh, both the Sharia Economic Law Compilation and Islamic Law Compilation are included in the phase after the grant property is given, then: In the Sharia Economic Law Compilation regarding the withdrawal of grant property, it is allowed to be withdrawn, except, among other things, there must be approval from the grantee or a court decision, if this does not exist then it is not allowed. If it is violated by the grantor of the grant, then the grantor is considered to have confiscated the property of another person. If the item is damaged or lost while in control, the grantor must replace it; In the Islamic Law Compilation, grant property can be withdrawn, only on grants from parents to their children. This is because the property given is considered an inheritance.; This is in line with Islamic fiqh which does not allow the gifted propertyto be withdrawn, as prohibited by RasûlullâhShallallahu 'alaihiwasallam in his words: "The person who withdraws his gift is like a dog who licks back his vomit' [HR. Al-Bukhâri]. 


\section{References}

Abdurrahman, Zulkarnain. (2018). Penarikan kembali hibah orang tua terhadap anak dalam pandangan para ulama. Jurnal Pemberdayaan Masyarakat, 6(1), 29-39. http://dx.doi.org/10.37064/jpm.v6i1.4991

Azni. (2015). Eksistensi Hibah dan Posibilitas dalam Perspektif Hukum Islam dan Hukum Positif di Indonesia. An-Nida, Jurnal Pemikiran Islam, 40(2).

Arikunto, Suharsini. (2002). Prosedur Penelitian: Suatu Pendekatan Praktek. RinekaCipta.

Djamali, Abdul. (2002). Hukum Islam berdasarkan Ketentuan Kurikulum Konsorsium Ilmu Hukum. MandarMaju.

H Veithzal, Rivai., Ardiyani, Komala. Nurhayati, Siti. (2009). Ekonomi Syariah: konsep, praktek dan penguatan kelembagaannya. PustakaRizki Putra.

Manan, Abdul \& Fauzan, M. (2001). Pokok-pokok Hukum Perdata Wewenang Peradilan Agama. Raja GrafindoPersada. , (2008). Aneka Masalah Hukum Perdata Islam di Indonesia. Prenada Media Group.

MD, Mahfud., Tono, Sidik., \& Muttaqien, Dadan. (1993). Peradilan Agama dan Kompilasi Hukum Islam dalam Tata Hukum Indonesia. UII Press.

PPHIMM. (2009). Kompilasi Hukum Ekonomi Syariah. Kencana.

Ramulyo, Idris. (2004). Perbandingan Hukum Kewarisan Islam dengan Kewarisan Kitab Undang-Undang Hukum Perdata. SinarGrafika.

Rusydi, Ibnu. (2016). Hibah dan hubungannya dengan kewarisan menurut Kompilasi Hukum Islam dan Hukum Perdata. Jurnal Ilmiah Galuh Justisi, 4(2), 212-224. http://dx.doi.org/10.25157/jigj.v4i2.324

Soekanto, Soerjono \& Mamudji, Sri. (1995). Penelitian Hukum Normatif Suatu Tinjauan Singkat. Rajawali Press. 